\title{
Ideology, Instrumentality and Economics Education: on the Secretion of Values within Philanthropy, Financial Capability and Enterprise Education in English Schools
}

Howard Gibson

\begin{abstract}
In England state provision for economics education in schools has been negligible. Except for a marginal number of students opting to study economics at secondary level, the subject has been largely limited to implicit lessons in philanthropy through liberal activities such as fundraising for charity and the like. Now, however, New Labour has countered this neglect by adding Personal Financial Capability and Enterprise and Entrepreneurial Education to the statue book. This paper takes issue with both the implicit and explicit curriculum for economics education in an attempt to uncover its assumptions and critique underlying policy.
\end{abstract}

Introduction

State provision for economics education in both primary and secondary schools has been negligible in England. Howard Davies, former Deputy Governor of the Bank of England and advisor to Margaret Thatcher, had concluded in 2002 that pupils emerge from schools without knowledge of the 'basic concepts about finance and the economy' (Davies, 2002a: 7). More recently Peter Davies has suggested that this is common in other advanced industrial nations, like the US and Australia, where young people'leave school with an inadequate understanding of their current economic system, and ... know even less about the economic 
alternatives among which they, as citizens, could choose' (Davies, 2006: 22). This historical neglect, however, has recently been addressed by the government that has now legislated to augment the statutory curriculum for economics in England. Whether these initiatives have been constructed to promote students awareness of 'economic alternatives', or foreclose upon them, is a central theme of this paper.

It does so by critiquing philanthropy, financial skills and enterprise education, three aspects of policy that currently help shape economics education. While the learning of philanthropy has existed for many years in schools as a customary and self-evidently worthy practice, today it is given official approval by the school inspectorate. Since the 2005 inspection framework and the requirement that an assessment is made of pupils"economic well-being', schools are now regularly praised for their fundraising events (e.g. OFSTED, 2006, 2007a, 2007b, 2007c). Secondly, personal finance capability is a more recent and explicit aspect of policy emerging from central government of late that is said to reflect the skills pupils will need in order for them to live as functioning economic beings in the future, like knowing how and why they should save. And thirdly, enterprise and entrepreneurial education has mirrored the concern of central government to engender 'creativity' and 'innovation' in pupils in order to prepare the nation for future economic buoyancy within increasingly competitive global markets (DfES/DTI, 2005; FSA, 2006; FSA, 2007).

This examination is prefaced upon the assumption that values underpin economic policy and practices. Above we saw how Davies would wish that pupils develop further their understanding of 'economic alternatives' in order to meet their obligations as responsible, caring citizens (Davies, 2006). In order to do this they would need to have a clear awareness of how values underlie alternatives. Whitty has also suggests that values are embedded in the economics curriculum but that they have been secreted to ensure that pupils are 'taught the right lessons':'We have not yet seen the life and teachings of Adam Smith written in the school timetable, but we should not assume that the lessons of neo-liberalism are not being learnt' (Whitty, 2002: 94). The notion that neo-liberal values may influence education policy, and that these are historical, contentious and disputable, may inform Davies' suggestion that policy makers may be reticent to develop pupils' critical awareness of economic alternatives insofar as 'they may not relish the ability of an electorate to bring a well-informed critical capacity to bear on the government's economic performance' (Davies, 2006). It may also be that, because successive governments since the 1980s have been wedded to a neo-liberal economic agenda, it has become accepted wisdom that the central purpose of education has been to supply the work-world with a literate and numerate labour force ready for employment, not necessarily knowledgeable of the economic forces 
that underpin it, let alone critical of them. Therefore, before the examination of policy, the next section seeks to question the mechanism whereby issues of value can become ideological, assumed and naturalised, in discourses on policy. It does so by investigating the notion of instrumental reasoning.

\section{Values, instrumentality and ideology}

Today it is a common assumption in government that national economic needs should drive education policy. Selzer and Bentley, for example, suggest that 'to boost competitiveness in the knowledge economy, we must make radical changes to the educational system' (Selzer and Bentley, 1999). While such changes may seem clear and inexorable to policy advisors, the values underpinning them often remain implicit, unquestioned or secreted. In order to explain how values can come to appear naturalised or ideological, theorists, like Max Horkheimer and Jurgen Habermas, have posited how human reasoning can be portrayed as an instrument. Horkheimer argued in Critique of Instrumental Reason that in the twentieth century 'reason is considered to come into its own when it rejects any status as an absolute ... and accepts itself simply as a tool' (Horkheimer, 1974). The foregrounding of means to the exclusion of ends was a notion developed by Habermas who argued that it was most evident when instrumental forms of reasoning and knowledge associated with science and technology became placed in the service of capitalism and augmented way beyond their appropriate domain. Here, he argued, mechanisms for decision making were reduced to:

...the correct choice among strategies, the appropriate application of technologies, and the efficient establishment of systems (with presupposed aims in given situations); it removes the total social framework of interests in which strategies are chosen, technologies applied, and systems established, from the scope of reflection and rational construction' (Habermas, 1971:82).

But while the systematic avoidance of reflection upon premises and the secretion of values from judgement are now common practice, Habermas would also maintain that instrumental thinking is not simply malignant. It is functional. It realises defined goals under given conditions. It produces the efficient construction of runways, the technical smartness of identity cards, the scientific possibility of genetically modified crops, manages the effective deployment of troops in combat, and so on. But while instrumental reasoning organises the means that are appropriate for the effective control of reality, substantive actions demands the appraisal of normatively valued alternatives, namely, the appetite for runways, identity cards, GM crops or war. 
Max Weber can be taken to theorise the unapologetic dissolution of substantive reasoning and the deferment to instrumental forms. As a sociologist and economist at the turn of the nineteenth century, he argued that within the 'spirit of capitalism' (the subtitle of his Protestant Ethic) there was an inexorable logic to its expansion cultivated by the advancement of instrumental reasoning:

Man is dominated by the making of money, by acquisition as the ultimate purpose of his life. Economic acquisition is no longer subordinated to man as the means of the satisfaction of his material needs. This reversal of what we should call the natural relationship, so irrational from a naïve point of view, is evidently as definitely a leading principle of capitalism as it is foreign to all peoples not under capitalistic influence (Weber, 1930, my emphasis).

With the advances in formal reasoning, witnessed by the acceleration of science and technology, as well as adjudicating and administering procedures to establish the dependable regulation of entrepreneurship, Weber maintained that progress towards the bureaucratic state was imminent. With the ever increasing expansion of a system whose values, ends and goals were quite 'irrational' but inevitable, industrial nations lived within what he called an 'iron cage':'The capitalist economy of the present day is an immense cosmos into which the individual is born, and which presents itself to him ... as an unalterable order of things in which he must live' (ibid., my emphasis). There were no substantive choices to be made outside the cage. The economy advanced because movements in scientific, technological and bureaucratic structures 'progressed'. In short, for Weber instrumental rationality had taken hold of the world and presented itself to humans as a necessary, logical, unalterable system where functional imperatives dominated. It was, he prophesised, the collective structural condition of humanity in industrial societies.

But by preferencing formal or instrumental rationality over substantive reasoning, and by equating history with a particular economic form operating at the turn of the nineteenth century, Weber's critics have condemned him for his ideological assumptions (e.g. Marcuse, 1972; Habermas, 1971). The notion, for example, that capitalism would forever emend its efficiency and scope until 'the last ton of fossilized coal is burnt' (Weber, 1930) is, from a contemporary perspective, a potent reminder of where such narratives of apparently unbridled and unalterable historical progress may lead. While Weber cannot be blamed for not anticipating the consequences of the spirit of capitalism upon global warming a century later, he can, they imply, be blamed for placing it beyond the wit of humankind to control. In short, not only do economic alternatives exist but, in presenting an economic practice as unalterable, his thesis is ideologically flawed. 
If policies concerning economic education have not been challenged sufficiently for their apparently self-evident truths regarding the benefits of teaching pupils a particular set of economic skills and social attitudes they too may be ideological. Even words like creativity have lately been appropriated by educational policy makers to construct instrumental visions of the economy of the future:

This Government knows that culture and creativity matter. They matter because they can enrich all our lives, and everyone deserves the opportunity to develop their own creative talents and to benefit from those of others ...They also matter because creative talent will be crucial to our individual and national economic success in the economy of the future (Blair, 2001:3, my emphasis; see also Miliband, 2003)

Here Blair couples creativity in education to the future needs of the national economy. The assumption is that the production of a new, adaptive workforce rid of former prejudices about the supply and demand for labour in terms of linearity, conformity and standardisation, is the sole way forward if Western economies are to remain buoyant in future global contexts. As Blair's advisor, Ken Robinson, put it:

Our system of education is predicated on old assumptions about the supply and demand for labour ... New models of education for the post-industrial economies are struggling to emerge in many parts of the world. These models are being shaped by new patterns of work, by the accelerated impact of technologies and by new ways of living (Robinson, 2004a: 23; see also Robinson, 2001).

Here creativity appears supine to the needs of the economy with education policy at heel (see Gibson, 2005). The politico-economist's concern for creativity lies in the way it bridges financial and educational policy while less well disguised texts make the link with profit more explicitly:

In 1996, Unipart increased its profits by over $£ 32$ million and its productivity levels by 30 per cent, as a result of its creative learning culture. In 1998, Unipart had its seventh consecutive year of record breaking growth, with sales exceeding $£ 1.1$ billion...

At Unipart, creativity seems to come naturally - not because employees are expected to take a course on creativity and problem-solving, but because there is virtually nowhere in the life of the firm where creative learning is set aside.

... to boost competitiveness in the knowledge economy, we must make radical changes to the educational system (Seltzer and Bentley, 1999:37,66, 10). 
Beneath these Weberian-like uses of creativity for instrumental ends lie a set of values attributable to neo-liberalism. A contention of this paper is that it is upon these assumptions of how the economy must function that the tradition of teaching pupils philanthropy as well as the recent initiatives regarding economics education in English schools have been formed. The examination of policy that follows seeks, therefore, to examine the way in which values of questionable veracity have become embedded within it. While philanthropy may not be an explicit part of the National Curriculum, the next section probes the policy and practice of fund raising for charities and asks if this embedded constituent of economics education is seeped in liberal values and based on questionable assumptions that avoid contact with an unarticulated political agenda. The next section then reflects upon the government's programme for augmenting pupils' financial skills, suggesting they are not value-free as currently presented but part of a broader economic agenda. And the final section investigates whether the current policy for enterprise and entrepreneurial education deals adequately with issues of an epistemic and ethical nature.

\section{Philanthropy and economics education}

Schools commonly teach children the virtues of charitable donation. From hunger lunches to cake fairs, sponsored runs to school discos, money is often raised by pupils and given to good causes. Not only is this government policy (e.g. DfEE, 2000a) but schools are now regularly (ap)praised during school inspections for their philanthropic deeds. In February 2006, for example, Copythorne C.E. Infants School in Southampton received the inspectors' judgement that 'there are missed opportunities to further develop the pupils' awareness of the economic world outside the school' (OFSTED, 2006: 4), but by June 2006 had raised $£ 516$ by challenging parents to take part in a sponsored assault course involving climbing nets, tunnels, hoops and jumps, and had donated the money to a charity supporting 'pioneering asthma and allergy research at The University of Southampton's School of Medicine' (AAIR, 2007; see also Copythorne C. of E. Infants School, 2006). OFSTED report favourably upon secondary schools where they find 'confident young citizens who enjoy being involved in activities such as charity events' (OFSTED, 2007a:3). They approve of students who engage in 'fund-raising activities, which raise large amounts of money for their chosen charities' (OFSTED, 2007b: 6), and of schools where students are encouraged to 'raise money for other good causes, both at home and abroad' (OFSTED, 2007c: 6). The Independent School Inspectorate is similar in this regard. The Dragon School in Oxford, for example, has recently announced that $£ 360$ raised by a harvest cake sale was donated to a charity called World Vision (Dragon School, 2007) and their latest 
report (March 2006) confirms that philanthropy is a valued aspect of the school's curriculum:

Fundraising for charities has a high profile and is very wide ranging. Such activities are frequently initiated and organised by the pupils themselves. Support is given to both local charities, such as the homeless and the children's hospice, and those further away, such as the active links that the school has with poor children in Calcutta, Rio de Janeiro and South Africa (Dragon School, 2006: para.2.26).

What is not evident from these inspection reports, however, is whether the schools also taught their pupils about the political and economic assumptions underpinning charitable work. While it is acknowledged that this sort of enquiry would demand a different paper, it would be one that sought to discover if pupils at Copythorne had been asked to consider whether the state through taxation should be funding medical research at a university school rather than private donation? Or, in order to deepen their understanding of 'poor children' abroad, whether pupils at the Dragon School had also investigated the complex and possibly unjust economic web that surrounds childhood poverty and that debt relief for the poorest nations, for example, might be part of a structural solution that was needed to raise their fortunes (see Hertz, 2005; Mandel, 2007)? Or, indeed, whether the school had raised not only funds for World Vision but its pupils' awareness that one of their adopted charity's declared political goals was to 'blow the whistle' on G8 world leaders and compel them 'to keep the promises that they made to children and adults' (World Vision, 2007)?

The political nature of fund raising for charities rarely seems questioned in schools. In part this is because the Charity Commission in England controls their work by ensuring that 'organisations that are established to pursue political purposes cannot be charities' (Charity Commission, 2004: para. 12). And yet the notion that deprivation, homelessness, people's health, unemployment, ecological issues, civil liberties, animal rights, conservation and the myriad other issues that are the business of charities are not intimately entangled with politics is, for some, untenable (Burt, 1998; Burt and Taylor, 2001; Porritt, 2005). Amnesty International, for example, is a charity that aims explicitly'to procure the abolition of torture, extrajudicial execution and disappearance' (Amnesty International, 2007). Moreover, the link between the voluntary sector and government is today much more complex and involved. Charities like Barnardos now act as surrogates for the state and paid by the government for their work. In the mid-1980s only about 10 per cent of charitable resources came from the government but, by the end of the 1990s, charities like Barnardos received almost 45 per cent of their income from local 
government and other public funding bodies (see caritasData, 2007). While charities have had to make choices about the extent to which they work in financial partnership with government for fear of losing a critical footing on economic policy, those doing so now operate as proxy suppliers providing at lower cost what used to be state services (from home help to palliative care) and today cannot escape the pretence of active engagement in the political process. Furthermore, the link with politics is even more obvious in countries like the US with the rise of mega-charities. While England has so far escaped the excesses of philanthropy on the scale of the Gates Foundation, now worth more than $\$ 60$ billion, it raises serious political issues concerning questions of accountability, the challenge to democratic institutions as well as the legitimacy of what is in effect a body so powerful that it appears to substitute for government in its pursuance of foreign policy (Frumkin, 2006; Katz, 2007).

While the depictions of philanthropy in the work of William Blake, Charles Dickens and Robert Tressell were intended to draw attention to the way charities often leave rosy glows but social structures unquestioned and intact, today schools may be constrained in their role as appraisers of the complex political economy that underpins fund raising but that helps shape, rationalise and condone its assumptions. Further research about how schools may approach or ignore the political nature of philanthropy is needed here, but for Faulks the link between the education of the 'charitable citizen' and this broader political agenda was most clearly first manifest during the 1980s under the premiership of Margaret Thatcher:

The active citizen of Thatcherism was a law abiding, materially successfully individual who was willing and able to exploit the opportunities created by the promotion of market rights, while demonstrating occasional compassion for those less fortunate than themselves - charity rather than democratic citizenship was to be the main instrument of 'active citizenship' (Faulks, 2006).

Here Faulks links modern versions of charity with neo-liberalism and the economic policy of the 'rolling back' of the state. The economic and political assumptions that he invokes are explored in the next two sections, where the government's new policies for Personal Financial Capability and Enterprise and Entrepreneurial Education are questioned.

\section{Personal finance capability and the development of neutral skills?}

Since the turn of the century government policy for financial capability has seemed piecemeal and uncoordinated. In 2000 the Department for Education and Employment published Financial Capability through Personal Financial Education: 
Guidance for Schools for both Key Stages 1\&2 (DfEE, 2000a) and $3 \& 4$ (DfEE, 2000b) that indicated clearly 'the Government's wish to include financial capability as a topic at all key stages' (DfEE, 2000a:3). How far the policy succeeded is unclear but its advisory nature probably limited its impact. In 2004 the Every Child Matters agenda was made statutory with the provision that all children should 'achieve economic wellbeing', although what this might mean for augmenting their financial skills was not clear at that time (DfES, 2004a:E4). In 2005 the Qualification and Curriculum Authority circulated Sex and relationship education, healthy lifestyles and financial capability, suggesting that the latter was 'an important life skill' that would 'help young people move into adulthood with confidence in their ability to deal effectively and efficiently with the range of financial decisions they will have to make' (QCA, 2005, my emphasis). In 2006 the Financial Services Authority, a nongovernmental quango with a governing body appointed by the Treasury, published Financial Capability in the UK: Delivering Change (FSA, 2006). John Tiner, its Chief Executive, having 'reviewed in depth what works in improving financial capability' recommended that there should be'a new road map for delivering a step change in the financial capability of the UK population' (ibid.: 1). Indeed, from September 2008 personal finance education will become statutory for 11-14 year olds in England and 'pupils will be taught essential financial life skills through functional maths and in Personal Social and Health Education' (DfES, 2007).

However, specificity about what constitutes financial capability is not easy for the skills listed in different government publications vary. They include:

- learning to value 'contributions to charity' (DfEE, 2000a);

- 'how to look after money' (QCA, 2005);

- 'making real choices about spending and saving';

- 'develop skills to think ahead about financial needs';

- learning to live with people 'that have different financial circumstances';

- knowing how to 'budget';

- learning 'how to save for the future' (pfeg, 2007) as for a house or pension;

- 'bank accounts, spending, looking at mobile phone tariffs and how to access needs' (FSA, 2006);

- 'learning about risk and reward; investment and trade; personal budgeting; mortgages; interest rates; and balancing credit cards' (DfES, 2007).

What is clear, however, is that the reason given for pupils needing these skills is that 'the economy is rapidly changing' and that the 'flexible labour market','short term contracts' and 'greater longevity' will 'all have serious implications for how we undertake financial planning' (DfEE, 2000a). In essence: 
Financial capability is an important life skill for everyone: the ability to make financial decisions is the key to identifying and making best use of the opportunities in today's changing world... Developing financial understanding is the first step in ensuring that young people leaving school have the skills required to deal with everyday financial issues. (DfEE, 2000a: 4 and 6)

But in this narrative on personal financial skills assumptions are made about their neutrality in terms of their advent historically as well as their content. Until recently skills were seen more as a by-product of education. Today the National Curriculum enshrines them in law (DfEE, 1999:20-1) and until recently the Department for Education and Skills championed them in its very title. The ascendancy of transferable skills has coincided with the demand for a flexible workforce with greater generic competences:'People with the right skills are crucial to the success and competitiveness of any business and Britain's economy' (DfES/DTI, 2005). Whether such skills divorced from specific bodies of knowledge or physical challenges are transferable is not questioned here (see Higgins and Baumfield, 1998; Andrews, 1990; Johnson, 2001); that skills are detachable from cultural assumptions and portrayed as politically neutral is.

Take 'communication skills'. Communication is often presented as devoid of content. Not communication about the substance of something but, rather, the transferable, content-less skill of communication. The content, purpose or substantive issues contained in communication is assumed to come from elsewhere, a perspective, place or person unnamed. British Telecom, for example, in its education initiative Communication Skills for Life (BT, 2006), says that its aims are:'To help everyone in the UK understand and enjoy the benefits of improved communication skills' (but omits to explain this apparently self-evidence purpose); 'to make a difference' (but to whom or why is not discussed); to be 'constantly engaged' (but not for what reason); 'open to ideas, opinions and questions' (but whether this openness extends to argument about poor ideas or merely to the reception of any ideas no matter what, remains ambiguous), and so on. In other words, in BT's portrayal of communication skills as instrumental there seems no epistemological concern for the content of ideas and, in the absence of a theoretical understanding of how contested ideas might be communicated, politeness substitutes for a complex mechanism whereby substantive disputes might be raised.

More accurately, the proximity of 'communication' with 'skill' bristles with values and cultural assumptions:

the phrase 'communication skill' names a cultural construct, not a natural phenomenon with an objective existence in the world. Whether some 
person, or group of people, has good, bad or indifferent communication skills is entirely dependent on what 'communication' is taken to be, and what is thought to constitute 'skill' in it (Cameron, 2000: 128).

The same discoursal features of communication can therefore be seen as a skill in one historical period or culture but as pathogenic in another. Argument, for example, in a primary classroom in Russia is assumed to be a valuable skill (Alexander, 2001) but less so in English primary schools where non-judgementalism has emerged as culturally more valuable in practices like 'circle time' (Middlesbrough EiC Partnership, 2006),'peer mentoring' (Teachernet, 2007) and, indeed,'financial capability':'Iisten carefully to what everyone has to say valuing all contributions non-judgementally so that young people from different financial backgrounds are able to contribute to discussions on an equal footing and with equal confidence' (DfEE, 2000b: 12, my emphasis). In essence, the content of communication skills varies from age to age and from culture to culture, and the façade of neutrality is revealed by historical evidence of shifts in content and by a comparison of assumptions from different contemporary practices.

Personal financial skills too are contingent, contentious and ideological. The skill of 'non-judgementalism' in discussion about financial capability in classrooms, for example, where one of the methods suggested by the DfEE is to engender talk about 'young people's own financial situations', could be seen as appropriate and sensitive and avoid the embarrassment that pupils may feel when encountering other pupils from 'different financial circumstances' (DfEE, 2000a:11, 9). Equally, it could be seen as serving to preclude discussion of structural inequalities where issues of comparative wealth are placed beyond enquiry and judgement. Similarly, skills connected with 'bank accounts', learning how 'to access need' and understanding 'the importance of saving for the future', as for an education or pension, are grounded on the assumption of the planned withdrawal of the state in this regard (see FSA, 2007) where it will increasingly become the individual's responsibility as a self-regulating, self-interested unit, best able to make a 'personal' judgement about their own or their family's needs. Whether this project is right, wrong or inevitable is contentious and disputable. However, that pupils are not expected to develop an understanding of the contextual backdrop to personal financial skills is a concern.

Indeed, the context underpinning the introduction of financial capability in schools has been part of a broader macroeconomic programme for socio-economic change in England under Blair's premiership. The 'Third Way' had two linked aspects (Blair, 1998). An economic one, linked to neo-liberalism, and a social one, linked to New Labour discourses on individual responsibility, opportunity and citizenship. The 
economic project was an extension of Thatcherism and included a programme of liberalisation and the promotion of free competition as the most effective basis for market forces to ensure quality and efficiency. This involved the de-regulation of labour markets and the reduction of the role of law and state, giving economic agents greater freedom from state control and legal restrictions whereby they could optimise their skills and productivity and act 'reflexibly' so that they could move with the market. Privatisation was one consequence in which the public sector was sold off and the state diminished in its share of direct or indirect provision of goods and services to businesses and the community alike. In the residual public sector market proxies were constructed with the aim of encouraging market forces. There was also the reduction of direct taxation while augmenting indirect taxation devised to increase consumer choice and the expansion of market forces. And, with the abolition of tariffs, subsidies and control on foreign investments, free trade not only within but beyond the nation state has tried to encourage the mobility of capital and labour with the aim of stimulating global market forces (see Jessop, 2000; Jessop, 2002; Whitty, 2002; Olssen et al., 2004). Conjoined with this neo-liberal economic project has been a series of social regulatory policies. These have included the preparation of people for the move away from a culture of dependency upon the welfare state that has been portrayed as costly, overburdened, inefficient and incapable of eliminating poverty and mistakenly orientated to cash entitlements. This has been largely been realised by a 'welfare to workfare' programme, by providing incentives for people to find employment and by providing them with the necessary skills - or'a hand up rather than a hand out' (The Guardian, 2005) - and by a move towards'personal empowerment' and the clear message that there are 'no rights without responsibilities' (Giddens, 1998). In summary, the Keynesian welfare state was to be dismantled and replaced by a Schumpeterian workfare, one where the state's role is to create the structures for the successful operation of the market in which individuals will increasingly need to compete and plan for themselves as individuals, or as individual family units.

Education has become one of the prime carriers of this socio-economic project. It has acted as a conduit for ensuring that this new vision of social regulation is congruent with the economics of neo-liberalism. Developing the skills of financial capability in education has been intended to naturalise neo-liberalism and gives it an implicit endorsement. Education policy in this regard aims 'to make the continuing neo-liberal transformation acceptable and sustainable rather than to question or challenge it' (Jessop, 2000). It is deeply ideological in so far as it takes technological change and globalisation as given, depersonalises them, fetishises market forces and makes scant reference to the economic, political and social forces that drive these forces forward. The economic system is presented as natural 
and inevitable and imbued with a Weberian spirit in which the place of human actors in the construction of economic and social activity is concealed so that 'they' (economic forces) are presented as objective and inevitable and that 'we' (actors, subjects, humanity) need to adapt to them. The absence of any obvious agency helps bind 'us' to the necessity of economic propositions because 'financial decisions impact','changes happen' (as with student loans) and 'choices and decisions' are made (see DfEE, 2000a). Human actors or people are things to which events occur:'People need to... be skilled in managing their financial affairs' (ibid.: 5, my emphasis);'problems can arrive when people fail to manage their money' (ibid.: 5, my emphasis);'people are, more than ever before, being asked to take responsibility for managing their finances' (FSA, 2007, my emphasis). Not actors like multinational companies, transnational banks, strategic alliances among giant companies, the military-industrial complex, the World Economic Forum, the International Monetary Fund, the World Bank, the Organization for Economic Cooperation and Development, the World Trade Organization or the trans-national elite (Robinson, 2004b). Certainly not actors like trade unions. Thus the way the social-economic system is presented is not as a preference but a necessity, not a project but Weberianesque inevitability. And when globalisation, technological change and competition are depersonalised, human agency enters through the need for personal survival. Personal financial skills demand the learning of competences for use in a context that is cast as unalterable. Pupils are to learn them, not question or critique the assumptions upon which they are based. Nor learn about economic alternatives.

\section{Re-politicising enterprise and entrepreneurial education}

In 2001 the government requested an appraisal of enterprise education to be chaired by Sir Howard Davies then head of the Financial Services Authority. In 2002 his Review reported that the 'ultimate objective' of enterprise education was to forge 'a more dynamic economy' and 'the ultimate aim - more job and wealth creation' (Davies, 2002). With these unequivocal ambitions Davies described enterprise education as 'the ability to handle uncertainty and respond positively to change, to create and implement new ideas and new ways of doing things, to make reasonable risk/reward assessments and act upon them in a variety of contexts, both personal and work' (Davies, 2002:17). By 2005 Davies' recommendation, that all pupils should receive the equivalent of five days of enterprise learning each year, had been made statutory (Davies, 2002: 11; HMSO, 2005: para. 1.60, 5.20). In 2006 Chancellor Gordon Brown's budget reaffirmed central government policy:

Enterprise is a key driver of a modern, dynamic economy. A healthy business sector creates wealth and employment, generates competitive pressure 
that drives innovative activity, and improves the range, quality and prices of goods and services for consumers (HM Treasury, 2006: para. 3.23; see also DfES/DTI, 2005).

In January 2007 Oli Barrett, a self-made, online speed-dating millionaire, launched a UK wide scheme called 'Make Your Mark with a Tenner' in which all participating pupils in Key Stage 4 were loaned $£ 10$ and given a month in which to make a profit. In launching the idea Barrett announced he was confident that he would see'a huge array of innovative, inspiring and profitable businesses flourishing' (Barrett, 2007). The endeavour was widely heralded as a novel instrument for realising enterprise education, in keeping with both Davies' recommendations and Chancellor Gordon Brown's wider economic goals.

But within these and related discourses on enterprise education are secreted values. A critical examination of their language, such as the selection of nouns rather than verbs or the use of the passive tense, can help uncover how these values can become buried and assumed. Nominalisation, for example, involves an option in grammatical construction in which nouns are chosen instead of verbs and often used in conjunction with passive syntax. For example:'Howard criticised enterprise education' would become 'There was criticism of enterprise education'. Here the verb ('criticised') has become represented as a noun or nominalised form, a name ('a criticism'), and the subject ('Howard' in this case) removed. For some such grammatical preferences are significant for they point to 'clues' or 'traces' of alternative choices (Fairclough, 1992: 27; see also Hodge and Kress, 1993). For instance by removing the author 'Howard' above, processes normally associated with subjects making choices such as agency and responsibility are represented as background issues and my goals, values and intentions (that some may want to attributable to me) become disguised or obscured. In essence, like passive constructions, discourses that use nouns where verbs are an option can work to conceal not only the actor but their assumptions and values (see Fairclough, 1989, 1995, Carter et al., 2002; Hodge and Kress, 1993). Clearly these choices in many texts can be construed as appropriate and benign, insofar as they encode 'official' or 'formal' communication, but in government policy documents they are worth questioning simply because they can also embed issues of a substantive nature.

OFSTED and the Financial Services Authority (FSA), for example, both use nominalisations in their description of enterprising activity, as in 'the development of ideas' (OFSTED, 2004:6) and 'the drive to make ideas happen' (FSA, 2006), but also agent-less passive clauses such as 'tackling a problem,',identifying a need','breaking down tasks' and 'planning an activity' (OFSTED, 2004:6). In so doing they not only distort a process by leaving attributions of causality and responsibility unclear 
(Fairclough, 1989: 124) but omit the consideration of values that underlies the choice of 'a problem' (such as who is empowered to choose and define the problem); assumptions concerning broader questions regarding 'a need' (such as equal- or over-consumption); or the consequence of 'an activity' (such as upon the environment). In short, such language presupposes concurrence with unspoken premises and attempts to rally collusion.

Lexical choices in the documentation on enterprise education are also revealing. Many commentaries make what OFSTED call 'an important distinction' (OFSTED, 2004) between entrepreneurship and enterprise education. Caird, for example, suggests:

At the outset it should be pointed out that enterprising people are not specifically entrepreneurs, where an entrepreneur is defined as an innovative business owner-manager who takes calculated risks... Examples of enterprising people who are not associated with business may include such people as Baden-Powells (sic Powell), Bob Geldof, Emily Pankhurst, Martin Luther King, Margaret Thatcher, Ronald Biggs, and Erin Pizzy (sic Pizzey) (Caird, 1990).

Geldof, Thatcher and Pankhurst. But not Hitler. My aim here is not to enter the debate about how enterprise and entrepreneurial education are conceptually distinct (see for example Cummins and Dallat, 2004; Jones and Iredale, 2006; Rose, 1992; Skillen, 1992; Smyth, 1999), but to indicate how the absence of figures like Hitler is indicative of a more serious epistemological fissure in the way both are perceived. Thus, one might ask, what guides Cairn's choice of enterprising people? If Howard Davies is correct in his description of such individuals, that is, their ability to 'handle uncertainty','respond positively to change' and 'create and implement new ideas', Hitler was nothing if not enterprising. The distinction between enterprise and entrepreneurial activity is thus important for, in illustrating what enterprising people look like, by offering a seemingly eclectic assortment of individuals with apparently interesting personality traits, it unreflectively imports a set of values. It preferences what Caird herself calls the 'psychological characteristics of entrepreneurs and enterprising people' (ibid.:137, my emphasis) and neglects epistemological and ethical issue associated with the veracity of their truth claims and actions. The values Caird assumes in assembling her ad hoc list are thus secreted and, in conjoining 'enterprise' with 'people', she truncates reflection upon the consequences of their enterprising action. Thus in order to escape the dilemma of selecting charismatic leaders based upon subjective choices and undisclosed preferences, she would need to shift conceptually from psychology to philosophy and make judgements about what forms of enterprising activity were right or 
wrong, good or bad, just or unjust, and enter into a discussion why. While the process would open up complex ethical and epistemological issues, only then could Hitler be denied the attribute of being enterprising.

The purpose and consequence of enterprising activity thus needs to be made explicit. The use of policy phrases like 'tackling a problem,' 'identifying a need' and 'planning an activity' together with personal attributes like 'handling uncertainty' and 'responding positively to change', are uncritically complicit within a context where 'problems','needs' and 'activities' have been previously assumed. In its denial of alternatives or lack of awareness of them, its justification is Weberian and, in its relentless pursuit of 'a more dynamic economy', sustained by instrumental reasoning. In Barrett's entrepreneurial 'tenner' challenge, for example, the wider purview of substantive values is never made explicit. While he clearly proscribed unlawful acts in the making of profit (presumably the trafficking of illegal drugs and the like thereby acknowledging but assuming an ethical link between value and profit) he never fully articulates the relationship of entrepreneurialism with issues like equity, fairness, the role of the state, the link with the environment, and so on. In short, what goes unchallenged is a set of apparently self-evident truths regarding the benefits of innovation, entrepreneurialism and market forces (Jessop, 2002).

\section{Conclusions}

Earlier it was suggested that while Weber cannot be blamed for not anticipating the consequences of the spirit of capitalism upon global warming this century - of unalterable progress until 'the last ton of fossilized coal is burnt' - he can for placing it beyond the wit of humankind to control. In 2007 the Intergovernmental Panel on Climate Change (IPCC, 2007), based on a consensus of 400 of the world's most senior environmental scientists, anticipated that 250 million people across Africa could face water shortages by 2020 and that agricultural production in consequence would drop by 50 per cent; that 20-30 per cent of the world's plant and animal species were at risk of extinction if temperatures rose between 1.5 and $2.5^{\circ} \mathrm{C}$; and that crop yields in Central and South Asia were likely to decrease by 30 per cent, and so on (IPCC, 2007). In 2006 the Stern Review (Stern, 2006) commissioned by Chancellor Gordon Brown articulated its concern for the environment, not for its intrinsic worth but for the economic cost of global warming, and spelled out the case for a brisk response to the need to limit carbon emissions. Stephen Schneider representing the American Association for the Advancements of Scientists (AAAS) has argued:

Cost-benefit analyses alone, which often focus only on markets, cannot address global inequities around carbon generation and mitigation... To 
make reasoned and equitable decisions, policymakers need to look not just at the market impacts, but at other factors such as loss of human lives and biodiversity, and quality of life' (Schneider, 2007).

Schneider is speaking here neither as a scientist nor as an economist. He steps outside these domains when he places value upon 'mitigation,',equity,'loss of human life', 'biodiversity' and the 'quality of life'. They originate from a substantive source that has been marginalised in the government's programme for economics education where policies driven by a neo-liberal agenda have been presented as historically obligatory:'to boost competitiveness in the knowledge economy, we must make radical changes to the educational system' (Selzer and Bentley, 1999). There is little evidence to believe that recent changes to the curriculum for economics in England have been designed to promote students' awareness of 'economic alternatives'. Whether reports that link global warming with specific types of economic activity are exaggerated is not a judgement that can be made in this paper, but that this sort of issue has not been placed at the centre of the new initiatives is of concern. If 'the ultimate aim' of economic policy is 'more job and wealth creation' (Davies, 2002), the political and moral choices that underpin economic activity are minimised and alternative visions inhibited. Indeed, for some the implication that there is a singular view of a functioning economy is not only spurious but constructed to ensure that pupils are 'taught how to operate effectively as citizens within a current regime' (Davies, 2006). For others it highlights the way in which education has come to serve as a mechanism for 'system adaption' (see Young, 1992; Habermas, 1984).

While this has not been a paper concerned with articulating alternative visions of economics education - a future one will - these issues have been lying in the background. Such alternatives would require the re-evaluation of policies that hinged upon technical-instrumental solutions to global problems, like environmental degradation, inequality and poverty, and investigate more critically the self-evident benefits of entrepreneurialism, market forces and the 'fetish', as Hamilton depicts it, for relentless economic growth (Hamilton, 2003). It would be a curriculum that required students to consider more deeply the values inherent in currently, dominant economic policies and practices. It is one where they would learn to question the role and economic influence of the contemporary state and learn about the impact of globalisation upon the declining power of modern democracies (see Anderson, 2002; Bottery, 2003; Davies et al., 2002; Hertz, 2001; Hobsbawn, 2001; Gibson, 2006; Redwood, 2007). It would be one that engendered critical debate about alternative economic models, from Schumacher's Small is Beautiful (1999) to Porritt's Capitalism as if the World Mattered (2005), or ideas emerging from the New Economics Foundation designed to 'challenge mainstream 
thinking on economic, environment and social issues' (nef, 2007). It would be one that encouraged students to become more judgemental about tensions in government policy, such as the drive for economic growth through the expansion of UK airports (DfT, 2003) while simultaneously adopting what some see as 'delusional' policies to reduce carbon emissions (Watt, 2007). It would be a curriculum that may still encourage students to continue with their charitable work and become philanthropic, but one that also taught them about the politics of foreign aid, of 'odious lending', of 'debt relief as if morals mattered' (Mandel, 2007; see also Hertz, 2005) and of the appropriate role of the state in providing for social care and the like. In essence, through 'teaching that expose(d) values and assumptions implicit in each discourse' (Davies, 2006:25) it would be a curriculum in which students would learn that choices underpin the working of the economy and that these alternatives were their concern, as citizens and human beings.

\section{References}

Asthma and Allergy Information and Research (AAIR) (2007) Online: www.aaircharity.org (accessed 20 June 2007).

Alexander, R.J. (2001) Culture and Pedagogy: international comparisons in primary education, Oxford: Blackwell.

Amnesty International (2007) Online: www.amnesty.org (accessed 20 June 2007). Anderson, J. (ed.) Transnational Democracy: Political spaces and border crossings. London: Routledge.

Andrews, J.N. (1990) General thinking skills: are there such things?, Journal of Philosophy of Education Vol. 24, 71-9.

Barrett, O. (2007) Welcome to Make Your Mark with a Tenner. Online: www.starttalkingideas.org (accessed 18 April 2007).

Blair, T (1998) The Third Way: New Politics for the New Century. London: Fabian Society.

Blair, T. (2001) Foreword by the Prime Minister. In Culture and Creativity: The Next Ten Years. London: Department for Culture, Media and Sport.

Bottery, M. (2003) The End of Citizenship? The Nation State, Threats to its Legitimacy and Citizenship Education in the Twenty-First Century, Cambridge Journal of Education Vol. 33 (1), 101-22.

British Telecom (2006) BT Education Programme: Communication Skills for Life. Online: http://www.bteducation.org/communication (accessed 28 June 2006).

Burt, E. (1998) Charities and Political Activity:Time to Re-think the Rules, Political Quarterly, Vol.69 (1), 23-30.

Burt, E. and Taylor, J. (2001) Giving Greater 'Political Voice' to Charities in Scotland?, Public Money \& Management, Vol. 21 (4), 9-10.

Caird, S. (1990) What Does it Mean to be Enterprising?, British Journal of Management, Vol. 1,137-45.

caritasData (2007) Charity Reports by Fax - Barnardo's. Online: www.caritasdata.co.uk (accessed 21 June 2007). 
Carter, R. ., Reah, D., Sanger, K. and Bowring, M. (2002) Working with Texts: A core book for language analysis. London: Routledge.

Cameron, D. (2000) Good to Talk? Living and Working in a Communication Culture, London: Sage.

Charity Commission (2004) CC9 - Campaigning and Political Activities by Charities. Online: www.comisiwnelusennau.gov.uk/publications/ (accessed 20 June 2007).

Copythorne C. of E. Infants School (2006) Newsletter 18th July 2006 Vol.6 Issue 12. Online: www.copythorne.hants.sch.uk. (accessed 8 January 2008).

Cummins, B. and Dallat, J.P. (2004) Helping Teachers to Make Sense of How Enterprise and Entrepreneurship May Be Defined, Citizenship, Social and Economics Education: An International Journal, Vol. 6 (2), 88-100.

Davies, H. (2002) A Review of Enterprise and the Economy in Education, London: HMSO.

Davies, P., Howie, H., Mangan, J. and Jelhaj, S. (2002) Economic aspects of citizenship education: an investigation of students' understanding, The Curriculum Journal Vol.13 (2), 201-23.

Davies, P. (2006) Educating citizens for changing economies, Journal of Curriculum Studies Vol. 38 (1), 15-30.

Department for Education and Employment (DfEE) (1999b) The National Curriculum: Key Stages 1\&2, London: HMSO.

Department for Education and Employment (DfEE) (2000a) Financial Capability through Personal Financial Education: Guidance for Schools at Key Stages 1\&2, London: DfEE/QCA.

Department for Education and Employment (DfEE) (2000b) Financial Capability through Personal Financial Education: Guidance for Schools at Key Stages 3\&4, London: DfEE/QCA.

Department for Education and Skills (DfES) (2004a) Every Child Matters: Change for Children, London: DfES.

Department for Education and Skills/Department for Trade and Industry (DfES/DTI) (2005), Skills for Productivity, London: DfES.

Department for Education and Skills (DfES) (2007) Key Stage 3 Curriculum Review:

Mastering the basics, creating greater flexibility, protecting the classics. Online:

www.dfes.gov.uk (accessed 5 February 2007).

Department for Transport (DfT) (2003) The Future of Air Transport - White Paper and the

Civil Aviation Bill.Online:www.dft.gov.uk/about/strategy/whitepapers/air/ (accessed 17

May 2007).

Dragon School (2007) Charity and Fund Raising. Online: www.dragonschool.org (accessed 20 June 2007).

Dragon School (2006) Independent Schools Inspectorate (ISI), Dragon School Report, March 2006. Online: www.dragonschool.org (accessed 9 January 2008).

Fairclough, N. (1989) Language and Power. London: Pearson Education.

Fairclough, N. (1992) Discourse and Social Change, Cambridge: Polity Press.

Fairclough, N. (1995) Critical Discourse Analysis. London: Longman.

Financial Services Authority (FSA) (2006) Financial Capability in the UK: Delivering Change. Online: www.fsa.gov.uk/pubs/other/fincap_delivering.pdf (accessed 21 June 2007).

Financial Services Authority (FSA) (2007) Financial Capability in the UK: Creating a Step Change in Schools. Online: www.fsa.gov.uk/pubs/other/step_change.pdf (accessed 21 June 2007). 
Faulks, K. (2006) Rethinking citizenship education in England: some lessons from contemporary social and political theory, Education, Citizenship and Social Justice, Vol. 1 (2), 123-40.

Frumkin, P. (2006) Strategic Giving: The Art and Science of Philanthropy. Chicago: University of Chicago Press.

Gibson, H. (2005) What Creativity Isn't: the presumptions of instrumental and individual justifications for creativity in education, British Journal of Education Studies, Vol. 53 (2), 148-67.

Gibson, H. (2006) Education for Democracy and Citizenship in: J. Sharp, et.al. (eds.) Education Studies: an Issues-Based Approach, Exeter: Learning Matters.

Giddens, A. (1998) The Third Way: The renewal of social democracy, Oxford: Polity Press. Guardian (The) (2005) A hand up, not a handout, 2 November. Online:

http://66.102.9.104/search?q=cache:drDmcW0M7XwJ:politics.guardian.co.uk/blunkett/s tory $/ 0,1606397,00 . \mathrm{html}+\mathrm{hand}+\mathrm{up}+$ not+hand+out $\&$ hl=en\&ct=clnk\&cd=1\&gl=uk (accessed 21 June 2007).

HM Treasury (2006) Budget 2006 Report. Online: http://www.hm-treasury.gov.uk (accessed 20 June 2007).

Habermas, J. (1971) Toward a Rational Society. London: Heinemann Educational.

Habermas, J. (1984) Theory of Communicative Action. Boston: Beacon Press.

Hamilton, C. (2003) Growth Fetish. Sydney: Allen \& Unwin.

Her Majesty's Stationery Office (HMSO) (2005) 14-19 Education and Skills: Presented to Parliament by the Secretary of State for Education and Skills: Cm6476. Online: www.dfes.gov.uk/14-19/documents/14-19whitepaper.pdf (accessed 21 June 2007). Hertz, N. (2001) The Silent Takeover: Global Capitalism and the Death of Democracy. London: Heinemann.

Hertz, N. (2005) I.O.U. The Debt Threat and Why we must Defuse it. London: Harper. Higgins, S. and Baumfield, V.M. (1998) A Defence of Teaching General Thinking Skills, Journal of Philosophy of Education, Vol. 32 (3), 391-8.

Hobsbawm, E. (2001) Democracy can be bad for you, New Statesman, 5 March, 25-7. Hodge, R. and Kress, G. (1993) Language as Ideology, second edition. London: Routledge. Horkheimer, M. (1974) Critique of Instrumental Reason. New York: The Seabury Press. Intergovernmental Panel on Climate Change (IPCC) (2007) Climate Change 2007: The Physical Science Basis. Summary for Policymakers. Geneva: IPCC Secretariat.

Jessop, B. (2000) Good Governance and the Urban Question: On Managing the Contradictions of Neo-Liberalism. Online: www.comp.lancs.ac.uk/sociology/papers/ Jessop-Good-Governance-and-the-Urban-Question.pdf (accessed 4 May 2007).

Jessop, B. (2002) The Future of the Capitalist State. Cambridge: Polity.

Johnson, S. (2001) Teaching Thinking Skills. Ringwood: Philosophy of Education Society of Great Britain.

Jones, B. and Iredale, N. (2006) Developing an entrepreneurial life skills summer school, Innovations in Education and Teaching International, Vol. 43 (3) 233-44.

Katz, S. (2007) Philanthropy's New Math, Chronicle of Higher Education, Vol. 53 (22) B6-B9, $4 \mathrm{p}, 3 \mathrm{c}$.

Mandel, S. (2007) Odious Lending: Debt relief as if morals mattered. Online: 
www.neweconomics.org/gen/ (accessed 20 June 2007).

Marcuse, H. (1972) Negations: Essays in Critical Theory. London: Penguin.

Middlesbrough EiC Partnership (2006) Circle Time.

Online: www.eic-middlesbrough.gov.uk (accessed 20 June 2007).

Miliband, D. (2003) Minister for School Standards praises the value of arts and creativity in education. Online: http://www.artscampaign.org.uk/info/DMiliband1.html, talking at the national campaign for the arts, 12 November (accessed 6 July 2004). new economics foundation (nef) (2007) Online: http://www.neweconomics.org/gen/ (accessed 20 June 2007).

Office for Standard in Education (OFSTED) (2004) Learning to be enterprising: An evaluation of enterprise learning at Key Stage 4. London: HMI 2148.

Office for Standards in Education (OFSTED) (2006) Copythorne C.E. Infants School, Southampton, Inspection Report, February. Online: http://www.ofsted.gov.uk/reports/ (accessed 15 December 2007).

Office for Standards in Education (OFSTED) (2007a) Barr Beacon Language College, Walsall, Inspection Report, February (accessed 9 January 2008).

Office for Standards in Education (OFSTED) (2007b) The John Warner School, Herefordshire, Inspection Report, November (accessed 9 January 2008).

Office for Standards in Education (OFSTED) (2007c) The Duchess's Community High School, Northumberland, Inspection Report, October (accessed 9 January 2008).

Olssen, M., Codd, J. and O'Neil, A-M (2004) Education Policy: Globalization, Citizenship \& Democracy. London: Sage.

Personal Finance Education Group (pfeg) (2007) Developing financial capability through mathematics and PSHE: A Key Stage 3 Resource. Online: http://www.pfeg.org/Resources/ (accessed 20 June 2007).

Porritt, J. (2005) Capitalism: As If the World Matters. London: Earthscan.

Qualifications and Curriculum Authority (QCA) (2005) Sex and relationship education, healthy lifestyles and financial capability. London: QCA.

Redwood, J. (2007) Freeing Britain to Compete: Equipping the UK for Globalisation. Online: www.conservatives.com (accessed 7 January 2008).

Robinson, K. (2001) Out of Our Minds: Learning to be Creative. Oxford: Capstone.

Robinson, K. (2004a) At long last a break in the clouds, The Times Educational Supplement, 12 March.

Robinson, W.I. (2004b) A Theory of Global Capitalism: Production, Class, and State in a Transnational World. Baltimore: John Hopkins University Press.

Rose, N. (1992) Governing the enterprising self. In: P. Heelas and P. Morris (eds) The Values of the Enterprise Culture: The Moral Debate. London: Routledge.

Schneider, S. (2007) Scientists will discuss creating a culture of sustainability February 19 at AAAS. Online: www://euekalert.org/pub_releases/2007-02/su-swd021407.php (accessed 18 June 2007).

Schumacher, E.F. (1999) Small Is Beautiful: Economics as if People Mattered.Vancouver: Hartley \& Marks.

Selzer, K. and Bentley, T. (1999) The Creative Age: Knowledge and skills for the new economy. London: Demos. 
Skillen, A. (1992) Enterprise:Towards the emancipation of a concept. In: P. Heelas and P. Morris (eds) The Values of the Enterprise Culture: The Moral Debate. London: Routledge. Smyth, J. (1999) Schooling and enterprise culture: pause for a critical policy analysis, Journal of Education Policy, Vol. 14 (4) 435-44.

Stern Review (2006) The Economics of Climate Change. Online: www.hm-treasury.gov.uk (accessed 19 May 2007).

Teachernet (2007) Teaching and Learning: Learning to Mentor-- Peer Mentor Training. Online: http://www.teachernet.gov.uk/teachingandlearning (accessed 20 June 2007).

Watt, N. (2007) Carry on flying, says Blair - science will save the planet, Guardian Unlimited.Online: http://environment.guardian.co.uk (accessed 17 May 2007).

Weber, M. (1930) The Protestant Ethic and the Spirit of Capitalism. London: Unwin.

Whitty, G. (2002) Making Sense of Education Policy: Studies in the Sociology and Politics of Education. London: Sage.

World Vision (2007) Online: https://www.worldvision.org.uk (accessed 28 May 2007). Young, R. (1992) Critical Theory and Classroom Talk. Clevedon: Multilingual Matters.

\section{Contact Details:}

Dr Howard Gibson

School of Education

Bath Spa University

Bath BA2 9BN

UK

Email: h.gibson@bathspa.ac.uk 